\title{
POST STABILIZATION ESTIMATES OF MONEY DEMAND IN CROATIA: ERROR CORRECTION MODEL USING THE BOUNDS TESTING APPROACH
}

\author{
James E. Payne*
}

Abstract This paper estimates an error correction model of money demand for Croatia over the post-stabilization period based on the ARDL bounds testing procedure. While industrial production is statistically insignificant for both the M1 and M1A money demand specifications, interest rates, inflation, and the real effective exchange rate have a negative and statistically significant impact.The error correction money demand models appear structurally stable based on the cumulative sum and cumulative sum of squares test.

* James E. Payne, Department of Economics, Illinois State University, Normal, IL 61790, USA. 


\section{1 \\ INTRODUCTION}

The estimation of money demand and the stability of the money demand function has been a cornerstone of macroeconomic models and the implementation of monetary policy. While the money demand literature has focused on both industrialized as well as developed and less developed countries, there has been relatively few studies examining the money demand function for transition economies. The relative absence of empirical money demand studies for transition economies is due in part to the relative instability of these economies in the transition process itself as well as concerns over the reliability and frequency of time series data. In addition to the standard scale and opportunity cost variables in the money demand literature, the exchange rate and the role of currency substitution is believed to be an important factor in the money demand function for transition economies. However, the empirical research to date by Budina and van Aarle (1995), Budina et al. (1995), Nijsse and Sterken (1996), Payne (2000), Cota and Erjavec (2001), and Buch (2001) provide inconclusive evidence as to the importance of the exchange rate in the money demand function for transition economies.

While the early research on money demand function for Croatia focused on the pre-stabilization and very early post-stabilization periods (Anušić, 1994; Anušić et al., 1995; Babić, 1998), the focus of this study is to estimate the money demand function for Croatia since the anti-inflation stabilization program initiated in October 1993. With respect to the post-stabilization period, Payne (2000) finds that the opportunity cost variables of interest rates and inflation are statistically insignificant while the exchange rate has a negative impact on money demand, in that, as the domestic currency depreciates the demand for money declines. Cota and Erjavec (2001) find that interest rates are a relevant opportunity cost variable in the Croatian money demand function; however, Cota and Erjavec (2001) fail to incorporate the exchange rate and the possibility of currency substitution in their money demand specification. Although the poststabilization period covers a longer time horizon than the earlier studies, there are still limitations with respect to the number of observations and the overall time horizon, not to mention the statistical power of the unit root and cointegration tests (Hakkio and Rush, 1991; Kremers et al., 1992; and Lahiri and Mamingi, 1995). The methodological approach undertaken in this paper is the "bounds testing" procedure advanced by Pesaran et al. (2001), based on an unrestricted error correction model. The "bounds testing" procedure 
provides two main advantages over the standard cointegration analysis (Engle and Granger, 1987; Johansen, 1988; and Johansen and Juselius, 1990). First, the bounds testing procedure can be implemented regardless of whether the variables are integrated of order zero, $\mathrm{I}(0)$, or integrated of order one, $\mathrm{I}(1)$. Second, the appeal of the bounds testing procedure is that it can be applied to a small finite sample, as is the case in this study.

Section 2 briefly outlines Croatia's transition towards a market-oriented economy in terms of the behavior of money demand. Section 3 describes the bounds testing procedure, data, and results while Section 4 provides concluding remarks.

\section{2 \\ CROATIA'S TRANSITION AND THE BEHAVIOR OF MONEY DEMAND}

After declaring independence in 1991, Croatia inherited a hyperinflationary environment. The ensuing war with Serbia and Montenegro added to the inflationary pressures as deficit financing of the war as well as refugee aid resulted in monetization of fiscal deficits. With inflation averaging between 20 and 40 percent per month, the demand for real money balances declined due in part to inflationary pressures and currency substitution. In October 1993, the anti-inflation stabilization program was introduced which was comprised of a restrictive monetary policy stance, liberalization of the foreign exchange market and the exchange rate, control over public sector wage growth, restructuring of public utilities pricing, and the passage of a balanced budget (Anušić et al., 1995; Payne, 2000, 2002; Kraft, 2002). The stabilization program effectively changed the behavior of money demand with a reduction in expected inflation along with the appreciation of the nominal and real exchange rates. As a result of the reduction in inflation and appreciation of the exchange rate, households began to replace their foreign exchange savings and repatriation of deposits from abroad with domestic currency (i.e. reverse currency substitution), which resulted in an increase in real money balances.

With the growth in income along with increased lending, consumption spending on imports rose while at the same time exports failed to keep pace resulting in a substantial increase in the current account deficit by 1997. At the same time of the escalation of the current account deficit, the excessive risk taking on the behalf of banks led to several bank failures in 1998 and 1999. The combination of the current account deficit and banking 
crisis resulted in a recession. With a depreciation of the currency and lack of confidence in the banking system, currency substitution took hold. By the beginning of 2000, the banking crisis subsided as the newly elected government pursued fiscal consolidation, providing a more independent stance for monetary policy.

\section{3 \\ BOUNDS TESTING, DATA, AND RESULTS}

The use of an error correction specification for money demand is conditional on the assumption that the variables entering the money demand function are I(1). It is widely known that unit root tests have low power, which is especially true in the case of the alternative that the respective time series exhibit a persistent, yet stationary pattern (Canova, 1994). However, the autoregressive distributed lag (ARDL) bounds testing approach set forth by Pesaran et al. (2001) does not require any assumption as to whether the time series are $\mathrm{I}(1)$ or $\mathrm{I}(0){ }^{1}$

In the implementation of the ARDL bounds testing approach, we follow Mundell (1963) in that money demand maybe influenced by exchange rate movements in addition to the interest rate and the level of income. Moreover, inflation, measuring the return on physical assets, is also incorporated into the money demand function. ${ }^{2}$ The unrestricted error correction model is specified as follows: ${ }^{3}$

\footnotetext{
Tang (2002) implements the bounds testing procedure in the examination of money demand in Malaysia.

2 While Cuddington (1983) suggests incorporating both a foreign interest rate and exchange rate to capture capital mobility and currency substitution, respectively into the money demand function, the foreign interest rate was found to be statistically insignificant in preliminary estimates of the ARDL bounds testing procedure. Hence, the foreign interest rate was omitted in the analysis. The omission of the foreign interest rate is not unique (see Hamburger, 1977; Bahmani-Oskooee et al., 1998, among others) on several grounds. First, the integration of global financial markets and international arbitrage often result in the equalization of interest rates in different countries, known as the interest rate parity condition. Second, studies that include both foreign and domestic interest rates in the money demand specification encounter severe multicollinearity problems.

3 Preliminary estimates of money demand, using the ARDL bounds testing procedure, incorporated dummy variables for military action, banking crisis, and introduction of the value added tax. The dummy variables were statistically insignificant. Moreover, the exchange rate measured by the nominal effective exchange rate was also statistically insignificant. The use of the real exchange rate parallels the work by Bahmani-Oskooee and Pourheydarian (1990), Bahmani-Oskooee (1991), Bahmani-Oskooee and Malixi (1991), Arize and Shwiff (1993), Bahmani-Oskooee and Rhee (1994), and Welwita and Ekanayake (1998).
} 


$$
\begin{aligned}
& \Delta L R M_{t}=\alpha_{0}+\sum_{i=1}^{n} \alpha_{1 i} \Delta L R M_{t-i}+\sum_{i=1}^{n} \alpha_{2 i} \Delta L I P_{t-i}+\sum_{i=1}^{n} \alpha_{3 i} \Delta R_{t-i} \\
& +\sum_{i=1}^{n} \alpha_{4 i} \Delta R E_{t-i}+\sum_{i=1}^{n} \alpha_{5 i} \Delta \pi_{t-i}+\delta_{1} L R M_{t-1}+\delta_{2} L I P_{t-1}+\delta_{3} R_{t-1} \\
& +\delta_{4} R E_{t-1}+\delta_{5} \pi_{t-1}+u_{t}
\end{aligned}
$$

where $\Delta$ is the first-difference operator. LRM denotes the natural logarithm of real money balances based on the monetary aggregates: M1 and M1A. M1 is defined as cash outside banks, deposits with the central bank by other banking institutions and other domestic sectors, deposit money banks' demand deposits. M1A is M1 plus demand deposits of the central government and funds with deposit money banks. Following Buch (2001), LIP serves as the scale variable given by the natural logarithm of the industrial production index, 1995=100. Industrial production is hypothesized to have a positive impact upon real money balances. $\mathrm{R}$ is the interest rate on deposits not indexed to foreign currency. $\pi$ is the inflation rate based on the retail price index, 1995=100. The interest rate and inflation variables are hypothesized to have a negative impact on real money balances. RE is the real effective exchange rate based on retail prices defined as the ratio of the Croatian kuna relative to foreign currencies; thus an increase in the real effective exchange rate means that the Croatian kuna is depreciating. With regard to the real effective exchange rate, Arango and Nadiri (1981) argue that if wealth holders evaluate their portfolios in terms of the domestic currency; a depreciation translates into an increase in the value of foreign securities held by domestic residents, thereby increasing the demand for the domestic currency. On the other hand, if the domestic currency depreciates and the public expects further depreciation there would be currency substitution away from the domestic currency (Bahmani-Oskooee and Pourheydarian, 1990). Thus, the real effective exchange rate may have a positive or negative effect on the demand for real money balances. All variables have been seasonally adjusted and cover the monthly time frame 1994:6 to 2002:8.

The first step in the ARDL bounds testing approach is to estimate equation (1) by ordinary least squares in order to test the null hypothesis that there is a long-run relationship among the variables by conducting a $\mathrm{F}$ test of the lagged levels of the variables, i.e. $H_{0}: \delta_{1}=\delta_{2}=\delta_{3}=\delta_{4}=\delta_{5}=0$. As noted by Pesaran et al. (2001), the F statistic follows a non-standard distribution irrespective of whether the variables are I(0) or I(1). Pesaran et al. (2001) provide two asymptotic critical values for 
the bounds testing procedure. If the F statistic is above an upper critical value, the null hypothesis of no long-run relationship can be rejected irrespective of the orders of integration for the time series. If the F statistic is below the lower critical value, the null hypothesis of no long-run relationship is accepted irrespective of the orders of integration for the time series. However, if the $\mathrm{F}$ statistic falls between the lower and upper critical values, the result is inconclusive. Table 1 reports the $\mathrm{F}$ statistic associated with the null hypothesis that there is a long-run relationship among the variables along with the asymptotic critical values of the bounds testing procedure. For both M1 and M1A, the F statistic exceeds the upper critical value at the 1 percent significance level, i.e. there is a long-run relationship.

Table 1

BOUNDS TESTS F STATISTICS, 1994:6-2002:8

\begin{tabular}{|l|c|cc|cc|cc|}
\hline Monetary Aggregate & F statistic & $\mathbf{1 0} \% \mathbf{~ C V}$ & $\mathbf{5 \%} \mathbf{~ V V}$ & \multicolumn{2}{|c|}{$\mathbf{1 \%} \mathbf{~ C V}$} \\
\hline M1 & $4.8724^{\mathrm{a}}$ & 2.26 & 3.35 & 2.62 & 3.79 & 3.41 & 4.68 \\
M1A & $5.6097^{\mathrm{a}}$ & 2.26 & 3.35 & 2.62 & 3.79 & 3.41 & 4.68 \\
\hline
\end{tabular}

Notes: Asymptotic critical values were obtained from Table CI(iii) Case III: unrestricted intercept and no trend for $k=5$ (Pesaran et al. 2001, p. 303). a denotes significance at the 1 percent level.

Given there appears to be a long-run relationship among the variables. Based on the Akaike information criterion, the following ARDL error correction model is specified in the case of each monetary aggregate.

(2) $\Delta L R M_{t}=\beta_{0}+\beta_{1} \Delta L I P_{t}+\beta_{2} \Delta R_{t}+\beta_{3} \Delta R_{t-1}+\beta_{4} \Delta R E_{t}+\beta_{5} \Delta \pi_{t}+\beta_{6} E C_{t-1}+e_{t}$

Table 2 reports the estimated error correction representation of the ARDL model for M1 and M1A, respectively. As evident from Table 2, the scale variable, the industrial production index, is statistically insignificant in both models. This finding is comparable to that found by Buchs (2001) in the case of Hungary and Poland. The opportunity cost variables, interest rates, inflation, and the real exchange rate, have a negative and statistically significant impact in both models. The error correction terms are statistically significant and similar in magnitude for both M1 and M1A money demand models. 
Table 2

\section{ERROR CORRECTION MODELS FOR M1 AND M1A, 1994:6 -2002:8}

(t statistics are in parentheses)

[p-values are in brackets]

\begin{tabular}{|c|c|c|c|c|}
\hline \multirow{2}{*}{ Independent Variables } & \multicolumn{4}{|c|}{ Dependent Variables } \\
\hline & \multicolumn{2}{|c|}{$\Delta L R M 1$} & \multicolumn{2}{|c|}{$\Delta L R M 1 A$} \\
\hline C & \multicolumn{2}{|c|}{$\begin{array}{l}-.7054 \\
(-1.01)\end{array}$} & \multicolumn{2}{|c|}{$\begin{array}{c}-.5617 \\
(-.7340)\end{array}$} \\
\hline$\Delta L I P_{t}$ & \multicolumn{2}{|c|}{$\begin{array}{c}.0405 \\
(.3877)\end{array}$} & \multicolumn{2}{|c|}{$\begin{array}{c}.0160 \\
(.1433)\end{array}$} \\
\hline$\Delta R_{t}$ & \multicolumn{2}{|c|}{$\begin{array}{c}-.0710 \\
(-3.60)^{\mathrm{a}}\end{array}$} & \multicolumn{2}{|c|}{$\begin{array}{c}-.0811 \\
(-3.88)^{a}\end{array}$} \\
\hline$\Delta R_{t-1}$ & \multicolumn{2}{|c|}{$\begin{array}{l}-.0345 \\
(-1.83)^{c}\end{array}$} & \multicolumn{2}{|c|}{$\begin{array}{l}-.0454 \\
(-2.26)^{\mathrm{b}}\end{array}$} \\
\hline$\Delta R E_{t}$ & \multicolumn{2}{|c|}{$\begin{array}{l}-.0225 \\
(-3.69)^{a}\end{array}$} & \multicolumn{2}{|c|}{$\begin{array}{l}-.0215 \\
(-3.31)^{a}\end{array}$} \\
\hline$\Delta \pi_{t}$ & \multicolumn{2}{|c|}{$\begin{array}{l}-.0385 \\
(-4.25)^{\mathrm{a}}\end{array}$} & \multicolumn{2}{|c|}{$\begin{array}{l}-.0340 \\
(-3.51)^{\mathrm{a}}\end{array}$} \\
\hline$E C_{t-1}$ & \multicolumn{2}{|c|}{$\begin{array}{l}.0581 \\
(-1.98)^{b}\end{array}$} & \multicolumn{2}{|c|}{$\begin{array}{l}.0598 \\
(-1.75)^{c}\end{array}$} \\
\hline Adj. $R^{2}$ & \multicolumn{2}{|c|}{.40769} & \multicolumn{2}{|c|}{.3764} \\
\hline$F$ & 12.40 & {$[.000]^{\mathrm{a}}$} & 11.06 & {$[.000]^{\mathrm{a}}$} \\
\hline$S C_{1}$ & $.4 \mathrm{E}-4$ & $.995]$ & .0131 & {$[.909]$} \\
\hline $\mathrm{SC}_{4}$ & .8041 & [.938 & .4503 & {$[.978$} \\
\hline$A R C H_{1}$ & .1463 & {$[.702]$} & .8643 & {$[.353]$} \\
\hline
\end{tabular}

Notes: $E C_{t-1}$ is the error correction term. $F$ is the overall $F$ statistic for the error correction model. $S_{1}$ and $S_{4}$ are the LaGrange multiplier tests for serial correlation at lags 1 and 4, respectively, distributed as chi-square with 1 and 4 degrees of freedom, respectively. $\mathrm{ARCH}_{1}$ is the autoregressive conditional heteroscedasticity test statistic distributed as chi-square with 1 degree of freedom.

We next examine the structural stability of the error correction models of money demand using the cumulative sum (CUSUM) and cumulative sum of squares (CUSUMSQ) of the recursive residuals tests (Brown et al., 1975). The cumulative sum test is useful for detecting systematic changes in the regression coefficients whereas the cumulative sum of squares test is useful in situations where the departure from the constancy of the regression coefficients is abrupt and sudden. Figures $1 \mathrm{~A}$ and $1 \mathrm{~B}$ 
display the cumulative sum and cumulative sum of squares test, respectively for the M1 error correction model. Both the cumulative sum and cumulative sum of squares statistics lie within the 5 percent critical bounds, suggesting the M1 error correction model exhibits stability. Figures 2A and 2B display the cumulative sum and cumulative sum of squares test, respectively for the M1A error correction model. As in the case of M1, both the cumulative sum and cumulative sum of squares statistics lie within the 5 percent critical bounds, suggesting the M1A error correction model exhibits stability.

Figure $1 \mathrm{~A}$

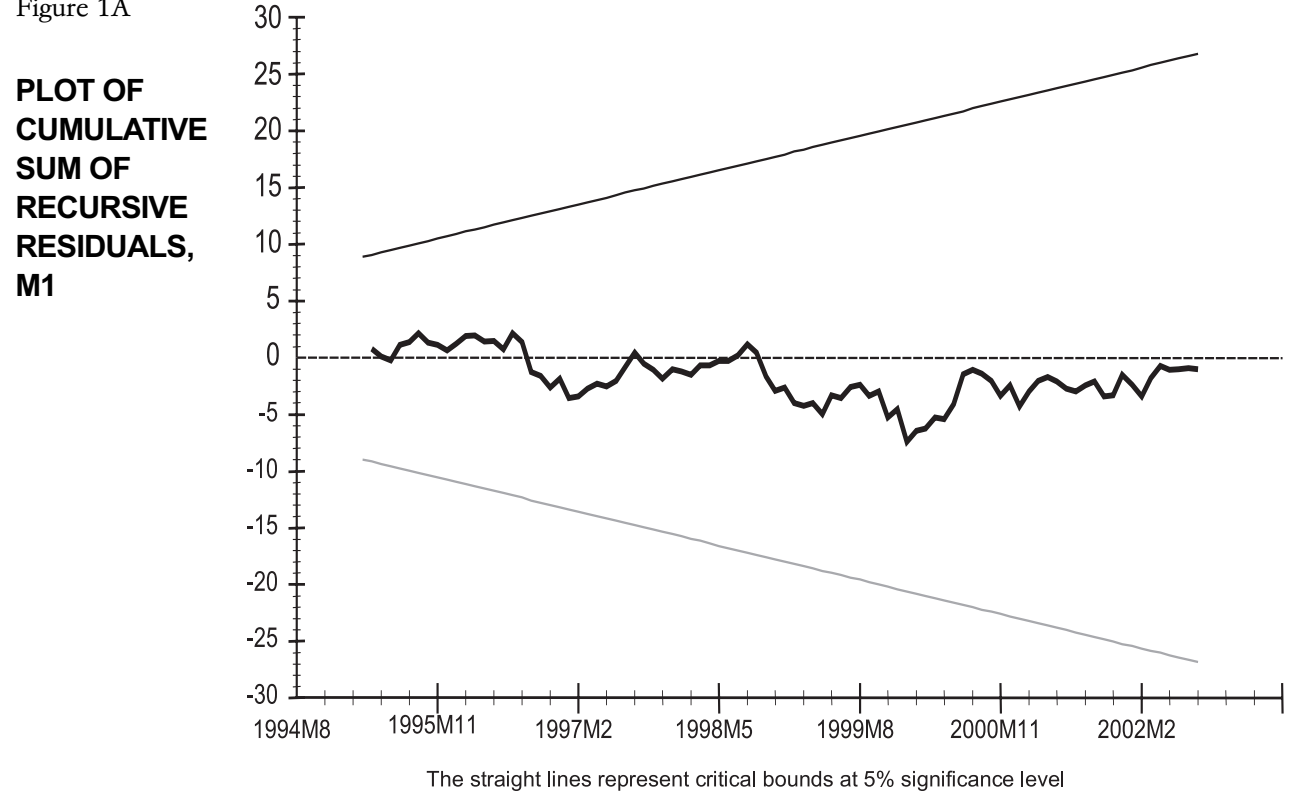




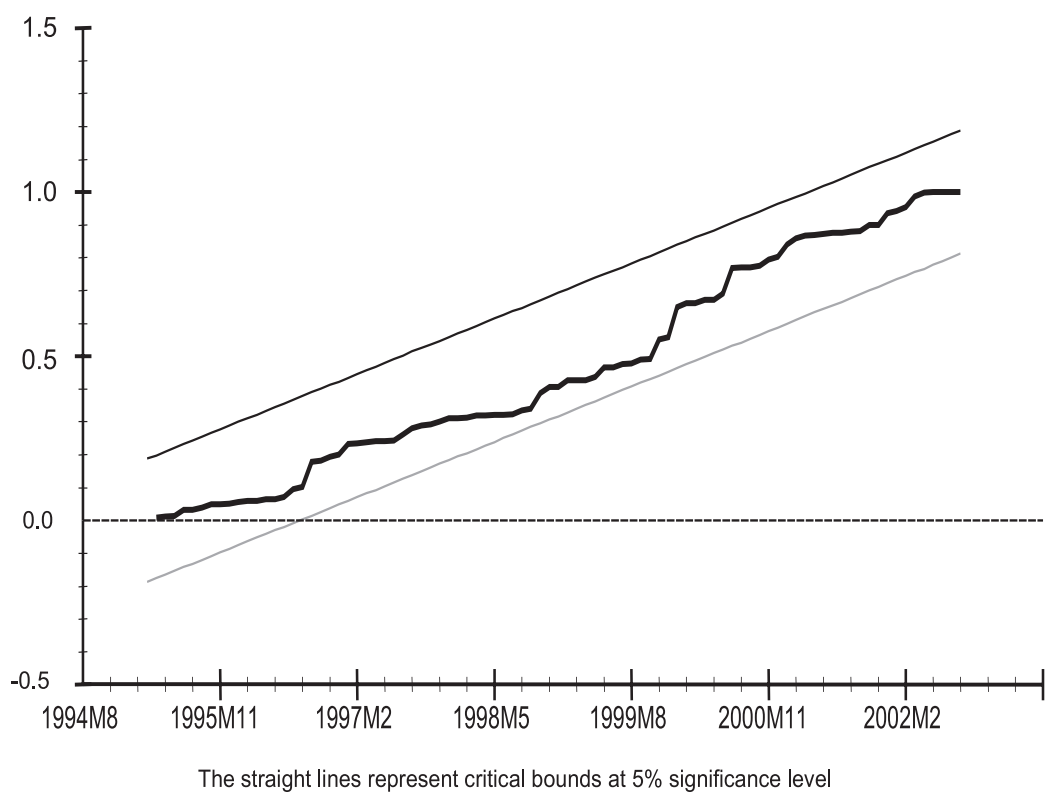

Figure 1B

PLOT OF

CUMULATIVE

SUM OF

SQUARES OF

RECURSIVE

RESIDUALS,

M1

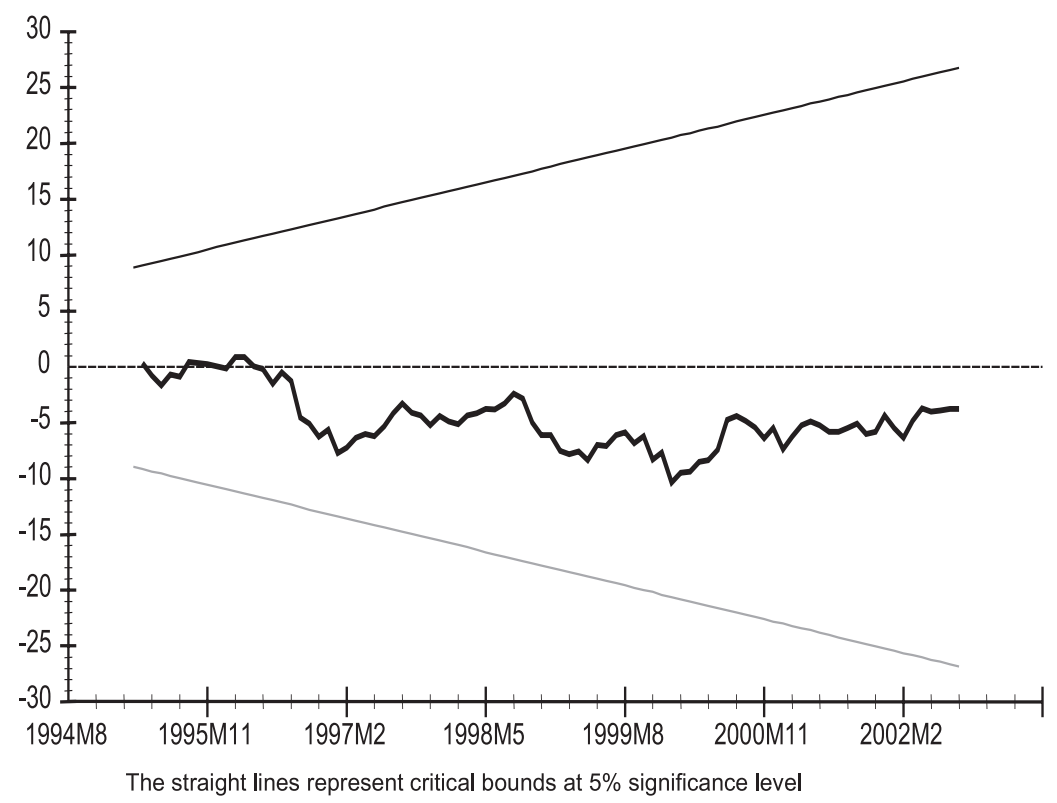

Figure 2A

PLOT OF

CUMULATIVE

SUM OF

RECURSIVE

RESIDUALS,

M1A 
Figure 2B

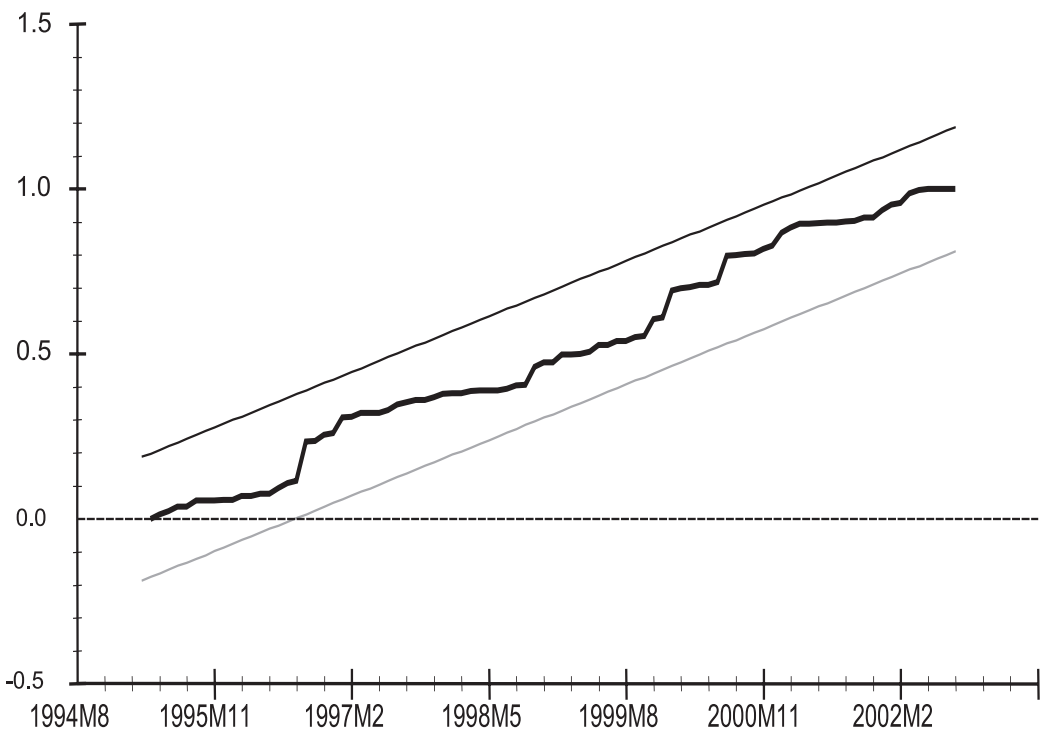

The straight lines represent critical bounds at $5 \%$ significance level

\section{4}

\section{CONCLUDING REMARKS}

This study provides additional evidence on the determinants of money demand function for Croatia using the bounds testing procedure advanced by Pesaran et al. (2001). Prior research by Payne (2000) and Cota and Erjavec (2001) provide conflicting evidence as to the determinants of money demand in Croatia. Payne (2000) estimated money demand using ordinary least squares to find that interest rates and inflation were statistically insignificant while the real exchange rate had a negative and statistically significant impact on money demand. Cota and Erjavec (2001) utilizing the Johansen-Juselius cointegration procedure find that interest rates are a relevant opportunity cost variable; however, Cota and Erjavec (2001) do not incorporate the role of the exchange rate in their analysis. Both studies suffer from the inability to adequately capture the long-run relationship among the variables specified in the money demand function due in large measure to the relatively small sample size as well as the low statistical power of the unit root and cointegration tests. The bounds testing procedure implemented in this study circumvents this problem on two fronts. First, the bounds testing procedure can be implemented regardless of 
whether the variables are $\mathrm{I}(0)$ or $\mathrm{I}(1)$. Second, the bounds testing procedure can be applied to small finite samples, as is the case in this study.

Our results reveal that the scale variable, industrial production, has a positive, but statistically insignificant impact on the error correction money demand functions. On the other hand, the opportunity cost variables of interest rates, inflation, and the real effective exchange rate have a negative and statistically significant impact on the error correction money demand functions. Moreover, cumulative sum and cumulative sum of squares tests reveal that the error correction money demand functions appear structurally stable. 


\section{REFERENCES}

Anušić, Zoran, 1994, "The Determinants of Money Demand in Croatia and Simulation of the Post-Stabilization Period", Croatian Economic Survey, Institute of Economics, Zagreb and National Bank of Croatia.

Anušić, Zoran, Željko Rohatinski, and Velimir Šonje, editors, 1995, A Road to Low Inflation: Croatia, 1993-1994, Zagreb: Government of the Republic of Croatia.

Arango, Sebastian, and M. Ishag Nadiri, 1981, "Demand for Money in Open Economies", Journal of Monetary Economics, 7, pp. 69-83.

Arize, Augustine C., and Steven S. Shwiff, 1993, "Cointegration, Real Exchange Rate and Modelling the Demand for Broad Money in Japan", Applied Economics, 25, pp. 717-726.

Babić, Ante, 1998, "Stopping Hyperinflation in Croatia, 1993-1994", Zagreb Journal of Economics, 2, pp. 71-114.

Bahmani-Oskooee, Mohoen, and Mohammad Pourheydarian, 1990, "Effects of Exchange Rate Sensitivity of Demand for Money and Effectiveness of Fiscal and Monetary Policy", Applied Economics, 22, pp. 917-925.

Bahmani-Oskooee, Mohoen, 1991, "The Demand for Money in an Open Economy: The United Kingdom", Applied Economics, 23, pp. 1037-1042.

Bahmani-Oskooee, Mohoen and M. Malix, 1991, "Exchange Rate Sensitivity of the Demand for Money in Developing Countries", Applied Economics, 23, pp. 1377-1384.

Bahmani-Oskooee, Mohoen and Hvun-Jae Rhee, 1994, "Long-Run Elasticities of the Demand for Money in Korea: Evidence from Cointegration Analysis", International Economic Journal, 8, pp. 83-93.

Bahmani-Oskooee, Mohien, Miguel G. Martin, and Farhang Niroomand, 1998, "Exchange Rate Sensitivity of the Demand for Money in Spain", Applied Economics, 30, pp. 607-612.

Buch, Claudia M., 2001, "Money Demand in Hungary and Poland", Applied Economics, 33, pp. 989-999. 
Budina, Nina and Bas van Aarle, 1995, "Currency Substitution, Seigniorage and Reform: The Case of Bulgaria, Poland, and Romania", Bank Review, 2, pp. 9-17.

Budina, Nina, Jan Hanousek and Zdenek Tuma, 1995, "Money Demand and Seigniorage in Transition", Eastern European Economics, 33, pp. 54-73.

Brown, R. L., J. Durbin, and John M. Evans, 1975, "Techniques for Testing the Constancy of Regression Relations over Time (with Discussion)", Journal of Royal Statistical Society, B37, pp. 149-192.

Canova, Fabio, 1994, "Testing Long Run Neutrality: Empirical Evidence for G7 Countries with Special Emphasis on Germany", Carnegie-Rochester Conference Series on Public Policy, 41, pp. 119-125.

Cota, Boris and Nataša Erjavec, 2001, "The Demand for Money in Croatia in Post Stabilization Period", Zagreb Journal of Economics, 8, pp. 81-112.

Cuddington, John, 1983, "Currency Substitution, Capital Mobility, and the Demand for Money", Journal of International Money and Finance, 2, pp. 112-133.

Engle, Robert F. and Clive W. J. Granger, 1987, "Co-integration and Error Correction: Representation, Estimating, and Testing", Econometrica, 55, pp. 251-276.

Hamburger, Michael J., 1977, "The Demand for Money in an Open Economy: Germany and the United Kingdom", Journal of Monetary Economics, 3, pp. 25-40.

Hakkio, Craig S. and Mark Rush, 1991, "Cointegration: How Short is the Long-Run?", Journal of International Money and Finance, 10, pp. 571-581.

Johansen, Soren, 1988, "Statistical Analysis of Cointegrating Vectors", Journal of Economic Dynamics and Control, 12, pp. 231-254.

Johansen, Soren and Katarina Juselius, 1990, "Maximum Likelihood Estimation and Inference on Cointegration with Applications to the Demand for Money", Oxford Bulletin of Economics and Statistics, 52, pp. 169-210.

Kraft, Evan, 2002, "Monetary Policy and Dollarization: The Case of Croatia" paper presented at the Croatian National Bank Conference, July 2002. 
Kremers, Jevoen J. M., Niel L. Ericsson, and Juan Dolado, 1992, "The Power of Cointegration Tests", Journal of Econometrics, 52, pp. 389-402.

Lahiri, Kajal, and Nlandu Mamingi, 1995, "Testing for Cointegration: Power versus Frequency of Observation-Another View", Economics Letters, 49, pp. 121-124.

Nijsse, Erwin and Elmer Sterken, 1996, "Shortages, Interest Rates, and Money Demand in Poland, 1969-1994", International Journal of Social Economics, 23, pp. 329-359.

Payne, James E., 2000, "Post Stabilization Estimates of Money Demand in Croatia: The Role of the Exchange Rate and Currency Substitution", Ekonomski Pregled, 51, pp. 1352-1368.

Payne, James E., 2002, "Inflationary Dynamics of a Transition Economy: The Croatian Experience", Journal of Policy Modeling, 24, pp. 219-230.

Pesaran, M. Hashem, Yongcheol Shin, and Richard J. Smith, 2001, "Bounds Testing Approaches to the Analysis of Level Relationships", Journal of Applied Econometrics, 16, pp. 289-326.

Tang, Tuck Cheong, 2002, "Demand for M3 and Expenditure Components in Malaysia: Assessment from Bounds Testing Approach", Applied Economics Letters, 9, pp. 721-725.

Weliwita, Ananda and E. M. Ekanayake, 1998, "Demand for Money in Sri Lanka during the Post 1977 Period: A Cointegration and Error Correction Analysis", Applied Economics, 30, pp. 1219-1229. 


\section{Ocjene post-stabilizacijske potražnje za novcem u Hrvatskoj: model s korekcijom odstupanja uz testiranje kritičnih vrijednosti}

Sažetak U ovom se radu ocjenjuje model s korekcijom odstupanja primijenjen na potražnju za novcem $u$ Hrvatskoj $u$ post-stabilizacijskom razdoblju. Model je zasnovan na testiranju kritičnih vrijednosti F-statistike uz autoregresivno distribuirane vremenske pomake neovisnih varijabli. Dok je industrijska proizvodnja statistički nesignifikantna i u M1 i u M1A specifikaciji, kamatne stope, inflacija i realni efektivni tečaj imaju negativan i statistički signifikantan utjecaj. Testovi kumulativnog zbroja reziduala i kumulativnog zbroja kvadrata reziduala pokazuju da je model s korekcijom odstupanja strukturno stabilan. 